\title{
HEAVY METAL RESISTANCE AND METALLOTHIONEIN INDUCTION IN BACTERIA ISOLATED FROM SEYBOUSE RIVER, ALGERIA
}

\author{
BENHALIMA, L. $^{1 *}-$ AMRI, S. $^{1}-$ BENSOUILAH, M. $^{2}-$ OUZROUT, $^{2}{ }^{2}$ \\ ${ }^{1}$ Department of Biology, Faculty of the Nature and the Life Sciences and the Earth and the \\ Univers Sciences, Université 8 Mai 1945 Guelma, Algeria \\ ${ }^{2}$ Laboratory of Ecobiology of Marine Environment and Coastlines, Faculty of Science, Badji \\ Mokhtar University, Annaba, Algeria \\ ${ }^{*}$ Corresponding author \\ e-mail: lamia-kos1@hotmail.fr, benhalima.lamia@univ-guelma.dz; phone: +213-663-479-379
}

(Received $10^{\text {th }}$ Oct 2019; accepted $23^{\text {rd }}$ Jan 2020)

\begin{abstract}
Heavy metal pollution is a serious and widespread environmental problem that destroys microbial ecology. In this study, determination of copper and cadmium concentrations and heavy metal-resistant bacteria identification in water samples obtained from four sites at Seybouse River in Algeria were carried out. The minimum inhibition concentration (MIC) and minimum bactericidal concentration (MBC) were determined in culture media with $12.5-3600 \mu \mathrm{g} / \mathrm{mL}$ of cadmium and copper salts. Metallothionein (MT) production was evaluated by spectrophotometry methodology. Trace metal element concentrations determined in the water samples revealed spatial variations for $\mathrm{Cu}$ and $\mathrm{Cd}$. A total of 12 copper- and cadmium-resistant bacteria (KZ1-KZ12) were isolated from surface water in Seybouse River. Five isolates KZ2, KZ5, KZ8, KZ10 and KZ11 showed high values of minimum inhibitory concentration ( $\mathrm{MIC}=3600 \mu \mathrm{g} / \mathrm{mL}$ ) for each heavy metal. High $\mathrm{MBC}$ of the strain toward $\mathrm{Cu}$ and $\mathrm{Cd}$ was found to be $>3600 \mu \mathrm{g} / \mathrm{mL}$. The MT concentration in five best isolates which showed high resistances increased with increasing metal concentration $(r=0.936, p=0.006)$. High levels of MT are detected in bacterial strains exposed to $\mathrm{Cd}$ (51.66-90.53 nmol MT/g bacterial biomass). These indicated that the isolates can be used efficiently in removal of heavy metals in contaminated sites.
\end{abstract}

Keywords: cadmium, copper, $M I C, M B C$, protein-binding

\section{Introduction}

Heavy metals are the main group of inorganic pollutants which are continuously accumulating in our environment (Manasi and Rajesh, 2016). In many developed and developing countries the heavy metal pollution has risen due to rapid industrialization, mining operations, discharge of industrial wastes, long term use of poor quality waters for irrigation and intensive agricultural practices (Rizvi et al., 2019). In recent years, heavy metal pollution in rivers, estuaries, and near-shore waters has become a serious problem ( $\mathrm{Li}$ et al., 2015). At high concentrations, cadmium and copper which are major contaminants found in the environment, are extremely poisonous to human(s), animals, plants and microbes which can damage cell membranes, alter particularity of enzymes, destroy the structure of DNA, bind the vital protein and cause further discrepancies (Jaishankar et al., 2014; Marzan et al., 2017). In regards to bacteria cells, pollution by heavy metals affects every aspect of bacterial metabolism and activity, structural inconsistency of the cytoplasmic membrane, retardation of the onset of growth, extending the lag phase of cultures, various structural abnormalities, decrease in the respiratory activity and death of the cells are some of the predominant ones (Aljerf and Almasri, 2018). 
Selective pressures from metal containing environments have led to the development of resistance systems in microorganisms to virtually all toxic metals. Bacteria strains have an array of mechanisms to deal with elevated concentrations of heavy metals and are often precise for one or few metals. This is achieved in different ways either through biological, physical, or chemical systems which include precipitation, complexation, adsorption, transport, product excretion, pigments, polysaccharides, enzymes, and specific metal binding proteins (Gupta and Diwan, 2017; Mutiat et al., 2018). Cysteine rich metallothionein proteins play an important role in immobilization of toxic heavy metals within the bacterial cell; thereby protecting their enzyme catalyzed metabolic processes (Choudhary, 2019). The thiol groups of cysteine residues enable MTs to bind essential and non-essential metalswith high affinity (Li et al., 2015). Due to metal detoxification property bacteria possessing metallothioneins are considered an ideal tool for bioremediation of heavy metal contaminated environments (Choudhary, 2019). Moreover, MT has been used as a biomarker of metal exposure in several ecotoxicological investigations (Mikawska et al., 2018).

Being an industrial city, Guelma province (Northeast of Algeria) is facing pollution problems. Heavy metals discharged from industries and agricultural activities pose threat to human population, aquatic biodiversity as well as agricultural environment. There are multiple causes for the water contamination in the Seybouse River Basin, which has been identified as one of the polluted rivers in Guelma province (Guettaf et al., 2014; Talbi and Kachi, 2019). Currently, direct diversion of untreated waste water from municipal areas, industrial wastage and extensive agricultural practices are observed along the banks of the Seybouse River. Land degradation is becoming a serious problem in the area, and recent studies have shown that the waters of the Seybouse River contain a series of heavy metals (Belabed et al., 2017; Talbi and Kachi, 2019).

One of the best ways to remove heavy metals from the environment, which recently have attracted a lot of interest, is the use of microorganisms. The use of microorganisms not only low cost and safe for the environment, but also has a high yield and is readily available (Mohseni et al., 2014). So, the study of bacteria with different resistance mechanisms is urgent, in order to discover potential candidates for the bio-removal of contaminants of diverse origins from the environment (Giovanella et al., 2017).

In this context, the present study aims to evaluate the levels of contamination by copper and cadmium in the surface waters of Seybouse River Basin, to isolate copper-resistant and cadmium-resistant bacteria, to identify those bacteria and their ability to induce metallothionein as a fundamental research to ensure the basis of their resistance in order to use them for detoxification in further bioremediation studies.

\section{Materials and Methods}

\section{Site description and sample collection}

The study area is located in the Seybouse watershed (Fig. 1), which is situated in the extreme Northeast of Algeria with a surface of about $6,471 \mathrm{~km}^{2}$ and has a population of 1.5 million. The river basin lies within the territories of Guelma province, El-Taref province (near Drean), and Annaba province. It is bordered in the north by the Mediterranean Sea, in the south by the Wilaya of Souk-Ahras, in the west by Edough Massif, Lake Fetzara, and in the east by Mafragh wadi (Louhi et al., 2012). Water of Seybouse River contributes in the irrigation of the plains of Guelma and Annaba provinces. The area is characterized by an annual average rainfall of $600 \mathrm{~mm}$, a more or 
less cool winter and a hot dry summer (Guettaf et al., 2014). Water samples were collected from four sites (S1, S2, S3, S4) in the middle of the Seybouse Basin (Guelma province) (Fig. 1). The characteristics of the sampling sites are shown in Table 1.

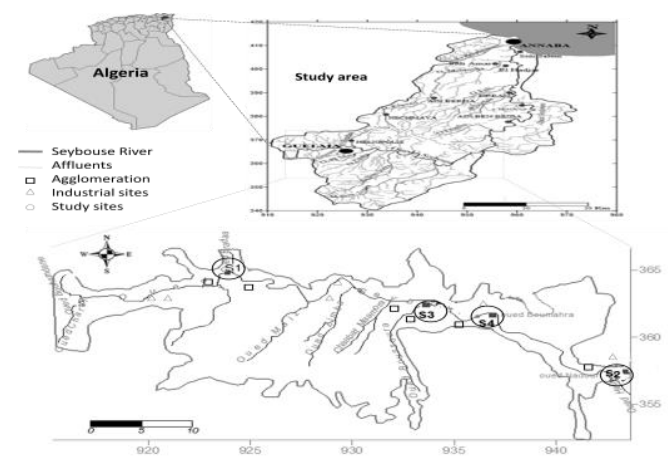

Figure 1. Map of the four selected sampling sites in Seybouse River. S1: Bradaa wadi, S2: Nadhor wadi, S3: Boussora wadi, S4: Boumahra wadi

Table 1. Characterization of sampling sites at Seybouse River (Source: author'sdata)

\begin{tabular}{c|c|c}
\hline Sampling sites & Geographic coordinates & Pollution \\
\hline Bradaa wadi (S1) & 36.29376 N 7.26483 E & Agricultural activities \\
Nadhor wadi (S2) & 36.25017 N 7.37485 E & Sewage effluents of canned tomato factory \\
Boussora wadi (S3) & 36.28113 N 7.32064 E & Agricultural water discharges \\
Boumahra wadi (S4) & 36.27427 N 7.31498 E & Sewage of marble factory \\
\hline
\end{tabular}

Twenty-four samples were collected from Seybouse River during two periods, March and April, 2019. At each sampling site, $500 \mathrm{~mL}$ water samples were collected for bacteriological analysis in sterile water sampling bottles (VWR, USA). Simultaneously, samples for trace metal elements (TME) were collected in $1.5 \mathrm{~L}$ decontaminated polyethylene bottles (VWR, USA). Water samples were acidified using $1 \% \mathrm{HNO}_{3}$ (REACH, Netherlands) to reach a $\mathrm{pH}$ lower than 2. Using a vacuum pump (MIDLAND, USA), $0.5 \%(\mathrm{v} / \mathrm{v})$ was filtered with a membrane of $1.2 \mu \mathrm{m}$ porosity (SARTORIUS, France) and then preserved at $0^{\circ} \mathrm{C}$ prior to TME analysis.

\section{Environmental factor measurements}

Water temperature (T), pH, salinity, dissolved oxygen (DO) and electrical conductivity (EC), were measured in situ at the time of sampling using a field multimeter (WTW Multi 340i, Germany). The concentrations of two trace metal elements $(\mathrm{Cu}$ and $\mathrm{Cd})$ in the water were determined using an Inductively Coupled Plasma-Atomic Emission Spectroscopy (ICP-AES, Thermo Electron IRIS Intrepid II XSP, USA). The results were expressed in $\mathrm{mg} / \mathrm{L}$ for water. All the measurements were performed in triplicate.

\section{Screening and characterization of metal-resistant bacteria}

Two metals $\left(\mathrm{Cd}^{2+}\right.$ and $\left.\mathrm{Cu}^{2+}\right)$ were selected for metal resistance screening based on a wide range of expected toxicities and their presence in water samples. Bacteria from the water samples were isolated using the spread plate technique. During routine culture 
and experimental procedures, bacterial cells were grown in liquid Luria Broth (LB) (pH 7.2-7.4) (KD Medical, Germany) in the presence of $100 \mu \mathrm{g} / \mathrm{mL}$ heavy metal and incubated at $37^{\circ} \mathrm{C}$ with shaking at $150 \mathrm{rpm}$ for $24 \mathrm{~h}$ (Xiaoyan et al., 2016). The metals were added as $\mathrm{CdCl}_{2} \cdot 2 \mathrm{H}_{2} \mathrm{O}$ and $\mathrm{CuSO}_{4} \cdot 5 \mathrm{H}_{2} \mathrm{O}$ (Merck, Germany). Control plates also prepared with LB media without including any heavy metal to make comparison. Individual distinct colonies were identified by their morphological and biochemical characteristics according to procedures described by Holt et al. (1994).

\section{Minimum inhibitory concentration (MIC) and Minimal biocidal concentration $(M B C)$}

The Minimal Inhibitory Concentration (MIC) for each metal-resistant bacterial isolate was determined using LB (KD Medical, Germany) containing different concentrations of one of the two heavy metals $\left(\mathrm{Cd}^{+2}, \mathrm{Cu}^{+2}\right): 12.5,25,50,100,200,400$, $800,1600,3200 \mu \mathrm{g} / \mathrm{mL}$. Metal salts $\left(\mathrm{CdCl}_{2}\right.$ and $\left.\mathrm{CuSO}_{4} 5 \mathrm{H}_{2} \mathrm{O}\right)$ were used to prepare 5 $\mathrm{g} / \mathrm{L}$ stock solution. Each stock solution was filter-sterilized and used for preparation of the final concentrations. After standardization of the inoculums, $1 \mathrm{~mL}$ of the diluted inoculums was added to $1 \mathrm{~mL}$ of each metal concentration except for the sterility control, which contained only LB (Keevil, 2001). Subsequently, the tubes were incubated in an oven at $37^{\circ} \mathrm{C}$ for $24 \mathrm{~h}$. Microbial growth was considered as positive in the tubes that showed any increase in turbidity or growth at the bottom. The MIC was defined as the lowest dilution with negative growth. To determine the minimum bactericidal concentration (MBC), a $10 \mu \mathrm{L}$ from those tubes, which did not show any visible growth in MIC assay, was cultured on LB agar (KD Medical, Germany) and incubated at $37{ }^{\circ} \mathrm{C}$ for 18 to $24 \mathrm{~h}$. The lowest concentration of metal producing no growth was considered to be the minimum bactericidal concentration (MBC). When growth was observed with the highest concentration of the antibacterial, the MBC was considered as the highest dilution and was indicated by the sign "greater than $(>) "$ (Keevil, 2001). Non-inoculated LB culture medium was used as the negative control and LB culture medium without the addition of metals as the positive control.

\section{Extraction and estimation of metallothionein (MT)}

Five best isolates (KZ2, KZ5, KZ8, KZ10 and KZ11) were selected based on degree of resistance to heavy metals. The metallothioneins (MTs) secreted by strains under heavy metal pressure were quantitatively assessed by the method of Murthy et al. (2011). The amounts of metallothionein in the samples were estimated using the GSH standard (Bio-tech, China), assuming that $1 \mathrm{~mol}$ of MT contains $20 \mathrm{~mol}$ of cysteine and were expressed in nmol/g bacterial biomass (Ana and Garcia-Vazquez, 2006). All experiments were performed in triplicate.

\section{Data analysis}

The data are expressed in mean values \pm standard deviation of the mean (SD). Statistical analysis of the data was performed using SPSS (Ver. 25.0, 2017), and the normal distribution was verified by applying the Kolmogorov-Smirnov, making it possible to choose parametric methods for the statistical analysis. Inter-site comparisons were performed using the analysis of variance (one-way ANOVA test). If significant difference between the mean values of the physicochemical parameters and TME concentrations in all studied sites was observed, Student-Newman-Keuils post hoc test 
was used to determine differences between study sites. Student's t-test was conducted to identify the significant differences between the MT variations. The correlation between MT levels and metal concentrations are evaluated by the Pearson correlation coefficient $(r)(p<0.05)$.

\section{Results}

\section{Environmental characterization}

The variations of physicochemical parameters and TME $(\mathrm{Cu}, \mathrm{Cd})$ in water are given in Table 2. The thermal water revealed similar mean values in the four sites $(\mathrm{p}=0.765)$. Regarding $\mathrm{pH}$, the analytical data revealed that water in the four sites was alkaline. Salinity and conductivity results showed that the maximum mean values are registered at site S4 and the lowest mean values are recorded at site S1. The dissolved oxygen levels reveal different means between the four sites, the highest level were recorded at site S3. The concentrations of the heavy metals investigated were significantly different between the different sampling sites (ANOVA, Student-Newman-Keuilspost hoc test). The maximum metal concentrations were observed at Bradaa wadi and Boumahra wadi for $\mathrm{Cu}$ and $\mathrm{Cd}$, respectively. The concentrations of copper in water were within the respective international and national recommended limits for natural water. For $\mathrm{Cd}$, the concentrations were above the limit of detection (Table 2).

Table 2. Variations of physicochemical parameters and TME concentrations in water samples analyzed at the four sampling sites of Seybouse River on March and April 2019 (Mean values $\pm S D, n=3$ )

\begin{tabular}{c|c|c|c|c|c|c}
\hline Variable & S1 & S2 & S3 & S4 & F-ratio & Sig. \\
\hline $\mathrm{T}\left({ }^{\circ} \mathrm{C}\right)$ & $7.1 \pm 0.05$ & $7.03 \pm 0.03$ & $7.12 \pm 0.01$ & $7.16 \pm 0.16$ & 0.388 & 0.765 \\
\hline $\mathrm{pH}$ & $8.0 \pm 0.04^{\mathrm{b}}$ & $8.03 \pm 0.02^{\mathrm{b}}$ & $7.83 \pm 0.01^{\mathrm{a}}$ & $8.65 \pm 0.01^{\mathrm{c}}$ & 159.11 & $0.000^{*}$ \\
\hline Salinity $(\mathrm{PSU})$ & $0.12 \pm 0.003^{\mathrm{a}}$ & $0.62 \pm 0.005^{\mathrm{b}}$ & $0.5 \pm 0.003^{\mathrm{c}}$ & $0.64 \pm 0.003^{\mathrm{d}}$ & 3431.28 & $0.000^{*}$ \\
\hline $\mathrm{DO}(\mathrm{mg} / \mathrm{L})$ & $6.52 \pm 0.1^{\mathrm{b}}$ & $7.24 \pm 0.01^{\mathrm{c}}$ & $7.82 \pm 0.01^{\mathrm{d}}$ & $6.21 \pm 0.01^{\mathrm{a}}$ & 6298.09 & $0.000^{*}$ \\
\hline $\mathrm{EC}(\mu \mathrm{S} / \mathrm{mg})$ & $898.7 \pm 0.33^{\mathrm{a}}$ & $1532.3 \pm 0.9^{\mathrm{c}}$ & $1335 \pm 0.33^{\mathrm{b}}$ & $1552 \pm 1.15^{\mathrm{d}}$ & 157880.94 & $0.000^{*}$ \\
\hline $\mathrm{Cu}(\mathrm{mg} / \mathrm{L})$ & $0.185 \pm 0.00^{\mathrm{d}}$ & $0.147 \pm 0.00^{\mathrm{a}}$ & $0.165 \pm 0.00^{\mathrm{b}}$ & $0.177 \pm 0.00^{\mathrm{c}}$ & 1203.67 & $0.000^{*}$ \\
\hline $\mathrm{Cd}(\mathrm{mg} / \mathrm{L})$ & $0.123 \pm 0.00^{\mathrm{b}}$ & $0.117 \pm 0.00^{\mathrm{a}}$ & $0.131 \pm 0.00^{\mathrm{c}}$ & $0.145 \pm 0.00^{\mathrm{d}}$ & 1329.0 & $0.000^{*}$ \\
\hline $\begin{array}{c}\text { Interntional and national threshols values for } \mathrm{Cu} \\
\text { concentrations in rivers }\end{array}$ & \multicolumn{2}{|c|}{$2 \mathrm{mg} / \mathrm{L}$} & Zaigham et al. $(2012)$ \\
OJAR $(2014)$
\end{tabular}

Sig: significance; ${ }^{*} p<0.001$ (one-way ANOVA); ${ }^{\mathrm{a}},{ }^{\mathrm{b}},{ }^{\mathrm{c}}, \mathrm{d}$ indicate significant differences by StudentNewman-Keuils post hoc test; S1: Bradaa wadi; S2: Nadhor wadi; S3: Boussora wadi; S4: Boumahra wadi. Limit of detection: $\mathrm{Cu}=0.1 \mu \mathrm{g} / \mathrm{L} ; \mathrm{Cd}=0.01 \mu \mathrm{g} / \mathrm{L}$

\section{Screening and characterization of metal-resistant bacteria}

Twelve metal-resistant bacteria were isolated from surface water in middle of Seybouse basin using a spread plate procedure, and were designated KZ1 to KZ12. Physiological and biochemical characterization of the bacterial strains was shown in Table 3. All of the bacteria were Gram-negative bacilli, smooth, sticky, non sporeforming and formed opaque colonies. Strain KZ5 produced a blue-green pigment that could be seen clearly in the liquid LB medium. This blue-green pigment, formed in the medium without $\mathrm{Cd}$, was not present in the medium containing $\mathrm{Cd}$, demonstrating that addition of Cd inhibits pigment formation (Fig. 2). 
Table 3. Physiological and biochemical characteristics of the heavy metal resistant bacterial strains

\begin{tabular}{|c|c|c|c|c|c|c|c|c|c|c|c|c|}
\hline Site & & S1 & & & S2 & & & S3 & & & S4 & \\
\hline Strain $N^{\circ}$ & KZ1 & KZ2 & KZ3 & KZ4 & KZ5 & KZ6 & KZ7 & KZ8 & KZ9 & KZ10 & KZ11 & KZ12 \\
\hline Glucose & + & + & - & + & + & + & + & + & + & + & + & + \\
\hline Sucrose & + & + & - & + & - & + & - & + & + & + & + & - \\
\hline Xylose & ND & - & - & + & + & ND & ND & + & - & - & ND & - \\
\hline Mannitol & + & + & - & + & + & + & - & + & - & + & + & + \\
\hline Maltose & - & + & - & + & + & + & - & + & - & + & + & - \\
\hline Rhamnose & + & + & - & + & - & - & - & + & - & - & + & - \\
\hline Lactose & + & + & - & - & - & - & - & + & - & - & - & - \\
\hline Melibiose & + & + & - & + & - & + & + & + & - & - & + & + \\
\hline Amygdalin & - & - & ND & + & ND & + & - & + & - & + & + & - \\
\hline Esculoside & - & + & - & + & + & - & - & - & + & - & + & - \\
\hline Arabinose & + & + & - & + & - & + & + & + & - & - & + & - \\
\hline $\mathrm{H}_{2} \mathrm{~S}$ & - & + & - & - & - & - & - & - & - & + & + & - \\
\hline $\begin{array}{l}\text { Simmons } \\
\text { citrate }\end{array}$ & - & + & - & + & + & + & + & + & - & - & + & - \\
\hline $\begin{array}{l}\text { Nitrate } \\
\text { reduction }\end{array}$ & - & + & + & + & - & + & - & + & + & + & + & + \\
\hline Uree & - & - & - & + & + & + & - & - & - & + & + & - \\
\hline Indole & + & - & - & + & - & - & - & - & + & - & - & - \\
\hline $\begin{array}{l}\text { Gelatine } \\
\text { liquefaction }\end{array}$ & - & + & + & - & + & + & - & - & - & + & + & - \\
\hline $\begin{array}{l}\text { Methyl red } \\
\text { test }\end{array}$ & + & + & - & - & - & + & - & + & - & + & + & + \\
\hline $\begin{array}{l}\begin{array}{l}\text { Ornithine } \\
\text { decarboxylase }\end{array} \\
\end{array}$ & - & - & - & + & - & - & - & + & - & - & + & - \\
\hline $\begin{array}{l}\text { Lysine } \\
\text { decarboxylase }\end{array}$ & + & - & - & + & - & + & - & + & - & - & + & - \\
\hline $\begin{array}{l}\text { Arginine } \\
\text { decarboxylase }\end{array}$ & + & + & - & + & + & + & - & + & - & - & + & - \\
\hline Catalase & + & + & + & + & + & + & + & + & + & + & + & + \\
\hline Oxidase & - & - & + & - & - & - & - & - & + & - & - & - \\
\hline VP test & - & - & - & + & - & - & + & - & - & - & - & - \\
\hline $\begin{array}{l}\beta- \\
\text { galactosidase }\end{array}$ & + & + & + & + & + & + & - & + & - & - & - & - \\
\hline $42^{\circ} \mathrm{C}$ growth & + & + & ND & ND & + & ND & - & + & ND & + & + & - \\
\hline $\begin{array}{l}\text { Identification } \\
\text { results }\end{array}$ & $\begin{array}{l}\text { Escherichia } \\
\text { coli }\end{array}$ & $\begin{array}{l}\text { Citrobacter } \\
\text { freundii }\end{array}$ & $\begin{array}{l}\text { Chryseobacterium } \\
\text { indologenes }\end{array}$ & $\begin{array}{l}\text { Raoultella } \\
\text { ornithinolytica }\end{array}$ & $\begin{array}{l}\text { Pseudomonas } \\
\text { aeruginosa }\end{array}$ & $\begin{array}{l}\text { Aeromonas } \\
\text { hydrophila }\end{array}$ & $\begin{array}{l}\text { Acinetobacter } \\
\text { baumannii }\end{array}$ & $\begin{array}{l}\text { Klebsiella } \\
\text { oxytoca }\end{array}$ & $\begin{array}{l}\text { Pasteurella } \\
\text { trehalosi }\end{array}$ & $\begin{array}{l}\text { Proteus } \\
\text { vulgaris }\end{array}$ & $\begin{array}{l}\text { Salmonella } \\
\text { Typhimurium }\end{array}$ & $\begin{array}{l}\text { Shigella } \\
\text { spp. }\end{array}$ \\
\hline
\end{tabular}

(+) indicates positive; (-) indicates negative; (ND) indicates not detected 


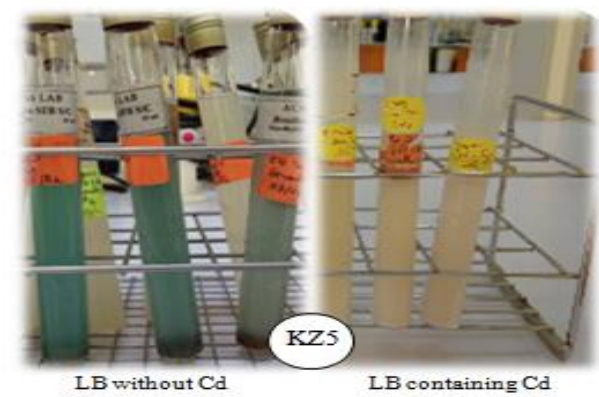

Figure 2. Inhibition of bleu-green pigment production by the isolate KZ5 after exposure to cadmium

\section{Minimum inhibitory concentration (MIC) and Minimal biocidal concentration $(M B C)$}

The order of MICs and MBCs for the majority of bacterial isolates was found to be $\mathrm{Cu}>\mathrm{Cd}$ (Table 4). More than $40 \%$ of the strains possessed maximum tolerable concentration equal or higher than $800 \mu \mathrm{g} / \mathrm{mL}$ metal (Fig. 3). KZ2, KZ5, KZ8, KZ10 and KZ11 are resistant against $\mathrm{Cu}$ and Cd with the highest MIC and MBC $(3600 \mu \mathrm{g} / \mathrm{mL}$ and $>3600 \mu \mathrm{g} / \mathrm{mL}$, respectively). Cadmium tolerance was higher for Pseudomonas aeruginosa (KZ5) (MBC > $3600 \mu \mathrm{g} / \mathrm{mL}$ ). Besides, Aeromonas hydrophila (KZ6) shows highest sensitivity to $\mathrm{Cd}$ as well as their resistance capacity against $\mathrm{Cu}$ are also lower compared to other bacteria. Comparison between all isolates to the same concentration of metal showed that the $p$ values were significantly different $(p=0.03)$.

Table 4. Minimum inhibitory concentration (MIC) and Minimal biocidal concentration $(M B C)$ of copper and cadmium against bacteria isolated from surface water

\begin{tabular}{c|c|c|c|c}
\hline \multirow{2}{*}{ Bacterial isolates } & \multicolumn{2}{|c|}{ Copper } & \multicolumn{2}{c}{ Cadmium } \\
\cline { 2 - 5 } & $\begin{array}{c}\text { MIC } \\
(\mu \mathrm{g} / \mathrm{mL})\end{array}$ & $\begin{array}{c}\text { MBC } \\
(\mu \mathrm{g} / \mathrm{mL})\end{array}$ & $\begin{array}{c}\text { MIC } \\
(\mu \mathrm{g} / \mathrm{mL})\end{array}$ & $\begin{array}{c}\text { MBC } \\
(\mu \mathrm{g} / \mathrm{mL})\end{array}$ \\
\hline KZ1 & 400 & 800 & 200 & 400 \\
KZ2 & 3600 & $>3600$ & 3600 & 3600 \\
KZ3 & 800 & 1600 & 400 & 800 \\
KZ4 & 800 & 1600 & 200 & 400 \\
KZ5 & 3600 & $>3600$ & 3600 & $>3600$ \\
KZ6 & 200 & 800 & 50 & 100 \\
KZ7 & 800 & 1600 & 100 & 400 \\
KZ8 & 3600 & $>3600$ & 3600 & 3600 \\
KZ9 & 1600 & 3600 & 800 & 1600 \\
KZ10 & 3600 & $>3600$ & 3600 & 3600 \\
KZ11 & 3600 & $>3600$ & 3600 & 3600 \\
KZ12 & 800 & 1600 & 200 & 400 \\
\hline
\end{tabular}

\section{Extraction and estimation of metallothionein (MT)}

Figure 4 shows the estimation of MT concentrations in the five best isolates (KZ2, KZ5, KZ8, KZ10 and KZ11). The MT concentration in the control (without metals) was zero whereas the levels of MT dosed are usually high at $1600 \mu \mathrm{g} / \mathrm{mL}$ metal compared to other metal concentrations. The MT level increased significantly $(r=0.936, p=0.006)$ 
in a metal concentrations. Results of this part revealed that $\mathrm{Cd}$ was the better inducer for MT than copper by the five isolates. The application of the Student's t-test for comparing the MT variation reveal a significant difference between MT concentration in the bacteria strains exposed to copper and MT content after exposure to cadmium $(p=0.005)$.

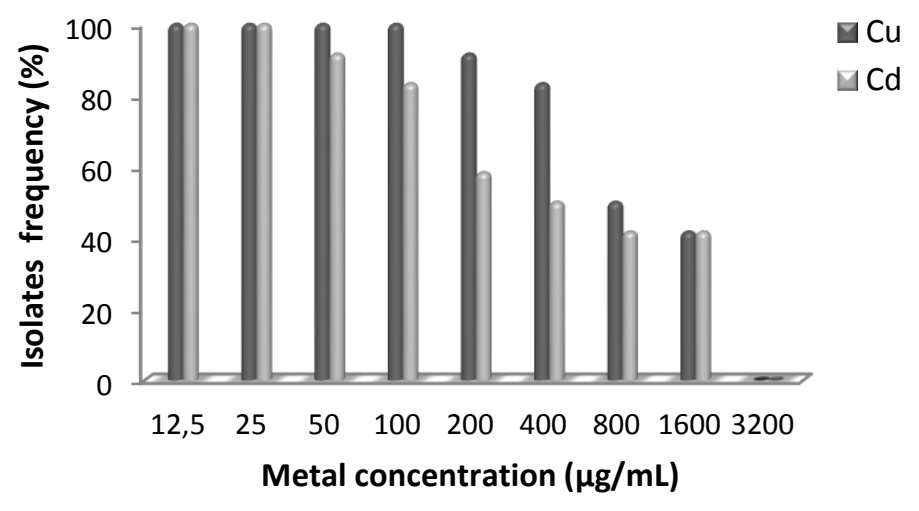

Figure 3. Percentage of metal-resistant bacteria in relation to concentrations of heavy metals
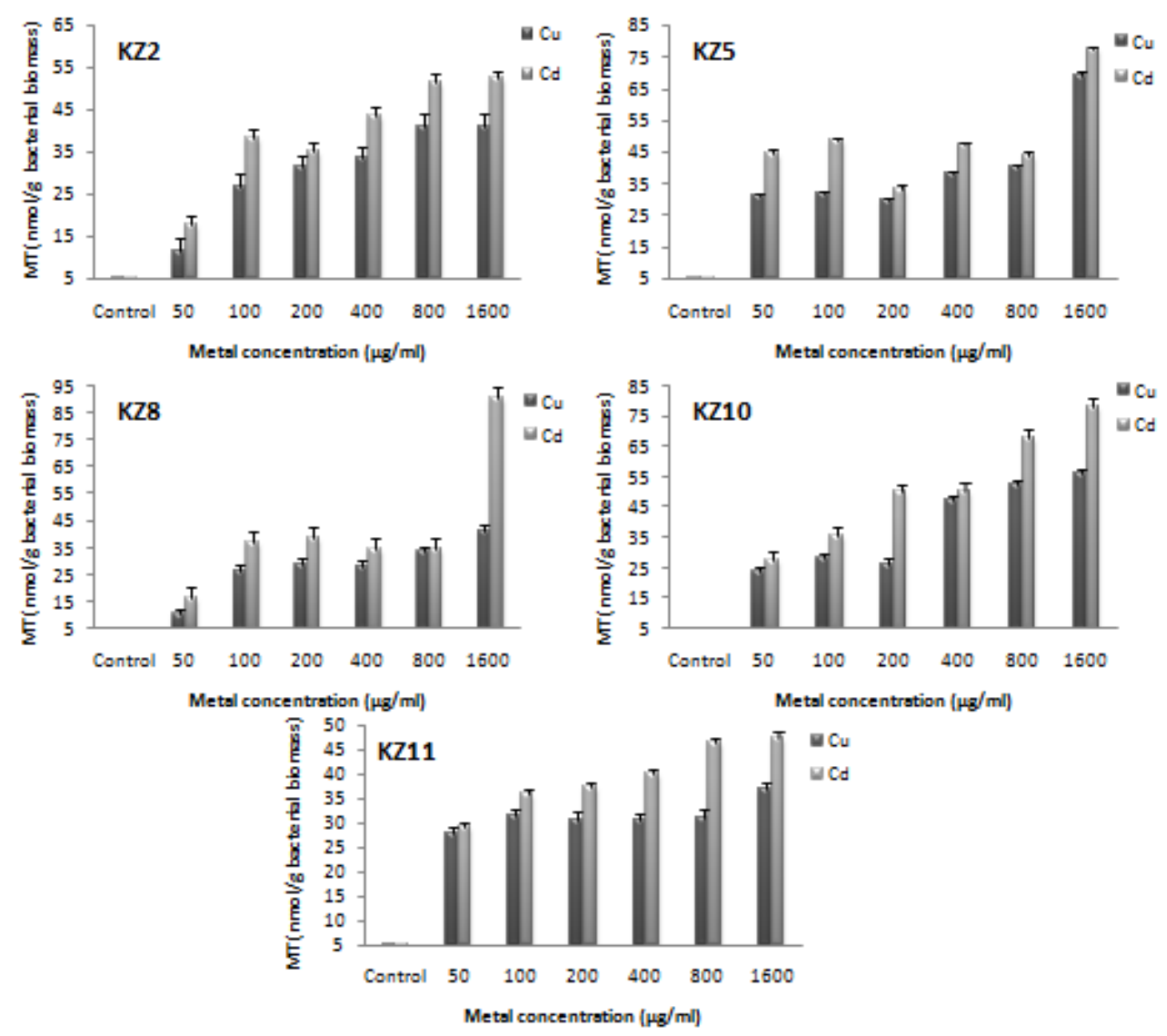

Figure 4. Metallothionein content in bacteria isolates treated with different concentrations of copper and cadmium 


\section{Discussion}

\section{Environmental characterization}

The thermal water revealed similar mean values in the four sites and it depends clearly on climatic conditions (Benhalima et al., 2018). The recorded $\mathrm{pH}$ values demonstrated a slight water alkalinity and did not show a variation between the sites $\mathrm{S} 1$ and S2 (Student- Newman-Keuils test). The $\mathrm{pH}$ of most freshwater systems is dependent on the mineral content of the surrounding rocks, soils and contamination by agricultural, urban or industrial discharges, and often ranges from 6 to 8 (Aminot and Kérouel, 2004). Generally, the optimum $\mathrm{pH}$ for bacterial growth is between 6.5 and 7.5. Salinity values were slightly low in Bradaa wadi (S1) compared to the other sites; this would probably be related to the dilution phenomenon during wet periods. CañedoArgüelles et al. (2019) indicate that urbanization and agriculture are the main drivers of river and stream salinization. The increase in conductivity at Nadhor wadi (S2), Boussora wadi (S3) and Boumahra wadi (S4) may be due to its proximity to the intense anthropogenic activities in this part of the basin. The dissolved oxygen levels reveal different means between the four sites, the highest level were recorded at site S3. Dissolved Oxygen is essential for the survival of the aerobic organisms present in the waterbody. In addition, microorganisms such as bacteria use the dissolved oxygen to decompose the organic material at the bottom of the water, which contributes to the recycling of nutrients (Eljaiek-Urzola et al., 2019). The high concentrations of dissolved oxygen during the study period can be explained by phytoplankton flares that can cause a temporary endogenous oxygen supply in aquatic environmental (Aminot and Kérouel, 2004). The results obtained of temperature, $\mathrm{pH}$ and the dissolved oxygen correspond with the work performed in the northeastern surface water of Algeria (Guettaf et al., 2014; Chaoui et al., 2015).

Heavy metal pollution is a worldwide predicament which disturbs the environmental equilibrium by gaining entry into the ecosystem due to their small size and bioaccumulation tendency (Manasi and Rajesh, 2016).The measured TME in the water of the four sampling sites revealed that the two elements $(\mathrm{Cu}$ and $\mathrm{Cd})$ are present. Copper concentrations in surface waters of surveyed wadis are not homogeneous (Student-Newman-Keuils test) but they do not exceed the international and national threshold values $2 \mathrm{mg} / \mathrm{L}$ (Zaigham et al., 2012; OJAR, 2014). The main source of $\mathrm{Cu}$ is telluric and would be related to the soil geology of this part of the Seybouse basin. In the study area, the importance of agricultural practices, traffic activities and municipal wastewater discharge is likely to increase transfers of $\mathrm{Cu}$ to surface waters. Jiang et al. (2017) indicate that copper distribution depends on the local dominance of farming and animal husbandry. In addition, Belabed et al. (2013) and Diop (2014) indicate that deterioration of sulfates (especially chalcopyrite and galenite) can increase sulfates and acidity justifying the presence of copper which increase is mainly related to the mining activity inducing trace metal mobilization. Also, DIOP (2014) indicate that copper are associated to sandy facieses directly exposed to waste discharges.

Concerning $\mathrm{Cd}$, its concentration was recorded above the international and national permissible limit $0.005 \mathrm{mg} / \mathrm{L}$ (Zaigham et al., 2012; OJAR, 2014) in all the water samples. Metals in higher concentrations displace the essential nutritional minerals in the living systems and prove deleterious to them by disrupting the functioning of vital organs making it a global environmental concern (Manasi and Rajesh, 2016). The high levels of cadmium in study sites may be explained by the leaching of agriculture lands 
enriched with phosphate fertilizers and industrial liquid wastes. Huanga et al. (2019) indicated that agricultural materials (including mineral fertilizers, organic fertilizers, pesticides, plastic films, etc.) have been highlighted as a major source of Cd. Results of this study are in agreement with the studies of Louhi et al. (2012), Khaled-Khodja et al. (2016), Belabed et al. (2017) and Talbi and Kachi (2019), who reported that the level of heavy metals increasing in the Seybouse rivers due to discharge of industrial effluents, the sewage discharged by the localities and the intensive use of chemical fertilizers and pesticides in agriculture.

\section{Screening and characterization of metal-resistant bacteria}

Results revealed a predominance of Gram-negative bacteria; the strains were predominantly glucose fermentatives bacteria, which belonged to the Enterobacteriaceae family. There are obvious differences in the physiological and biochemical characteristics of the twelve bacteria. The strains were identified as Escherichia coli, Citrobacter freundii, Chryseobacterium indologenes, Raoultella ornithinolytica, Pseudomonas aeruginosa, Aeromonas hydrophila, Acinetobacter baumannii, Klebsiella oxytoca, Pasteurella trehalosi, Proteus vulgaris, Salmonella Typhimurium and Shigella spp.

Pseudomonas aeruginosa did not form a blue-green pigment after exposure to cadmium. Bacterial pigments are known to protect the cell against any photo oxidative damage caused due to the toxic metal ions. So, the lack of pigment production indicates a toxic concentration of $\mathrm{Cd}$. It is already reported that at low metal concentrations, bacterial pigmentation is inhibited (Manasi and Rajesh, 2016).

Resistance in bacteria against these toxic metals reflects the threshold of environmental contamination and the direct or indirect exposure of these bacteria to the toxic compounds (Manasi and Rajesh, 2016). Bacteria have metal binding abilities and they are known to exhibit not only tolerance to metals but also their detoxification. There are many reports describing microbes, especially from enterobacteria and Pseudomonas genus, that are resistant to heavy metals. Niveshika et al. (2016) isolated $\mathrm{Cd}$ - and Cu-resistant strains of Proteus vulgaris, Serratia and Pseudomonas from water samples of Ganga River in India. Marzan et al. (2017) isolated Cd- resistant enterobacteria from tannery effluent in Chittagong city, Bangladesh. Türetken et al. (2019) isolated several metal-resistant bacterial strains from water samples collected from a Lake in Turkey.

\section{Minimum inhibitory concentration (MIC) and minimal biocidal concentration (MBC)}

The multi-metal resistance of the 12 bacterial strains of interest in liquid medium was tested by determining the minimal inhibitory concentrations (MIC) following a two-fold dilution technique approach. High MIC values indicate high tolerance of the bacterial isolate toward the metal and vice-versa.The results of growth pattern of bacterial isolates in presence of different of $\mathrm{Cu}$ and $\mathrm{Cd}$ concentration showed that all strains were multi-metal-resistant $(\mathrm{Cu}$ - and Cd-resistant). Several studies have shown the existence of multi-metal- resistant bacteria (Banerjee et al., 2015; Hoque and Fritscher, 2019; Türetken et al., 2019), and this is intimately related to the coresistance mechanism found in bacteria. Cai et al. (2019) demonstrated that flanked insert sequence elements on the heavy metal resistant genes suggested that horizontal gene transfer events may have resulted in multiple heavy metal resistance phenotypes and genotypes in bacterial strains. 
Upon above experiments, the resistance level $\mathrm{Cu}>\mathrm{Cd}$ showed for all bacterial isolates. This result may be explained by the fact that the toxicity of $\mathrm{Cu}$ is lower than $\mathrm{Cd}$. At lower concentration, copper is an essential trace element participating in many vital biological processes but at high concentrations, it exerts inhibitory action on bacteria by blocking essential functional groups or modifiying. On the other hand, bacteria cells have evolved and now provide complex and efficient regulation mechanisms to neutralize toxic copper (Li et al., 2019). While, cadmium is highly toxic, it is non-essential heavy metal element for all organisms that can accumulate in cells, where it disturbs the function of some enzymes and directly attacks nuclear DNA in microorganisms (Abbas et al., 2017; Chellaiah, 2018).

The continued environmental heavy metal pollution enables bacteria to develop resistance against these substances (Türetken et al., 2019). To counteract copper intoxication, bacteria can express a wide range of efflux systems to maintain metal ion homeostasis. Other copper resistance systems found in Gram-negative bacteria, such as the periplasmic multi-copper oxidase (e.g., $\mathrm{CueO}$ from $E$. coli), that oxidizes $\mathrm{Cu}^{1+}$ to $\mathrm{Cu}^{2+}$ were detected (Alquethamy et al., 2019). For cadmium, three metal resistance mechanisms in bacteria have been revealed: $\mathrm{Cd}$ ions can be prevented from flowing into cells by the presence of polysaccharides, proteins and fats on their surfaces; $\mathrm{Cd}$ can be expelled through efflux pumps and it can be chelated by intracellular metallothionein (Qin et al., 2019). However, aside from these mechanisms Cd resistant genes are present in plasmid DNA of Enterobacteria (Vidhyaparkavi et al., 2017).

Among all cultures, cadmium tolerance was higher for Pseudomonas aeruginosa. Pseudomonas aeruginosa is ubiquitous in water ecosystems and showed high resistance to heavy metals (Chellaiah, 2018). Various studies have been published of different heavy metal resistant mechanisms found in the genus Pseudomonas, as well as reports of chromosome and plasmid-encoded genetic determinants for resistance to heavy metals (Wrightet al., 2019). Many researchers have reported that $P$. aeruginosa as Cdand $\mathrm{Cu}$-resistant bacteria were isolated from different environment regions (Chen et al., 2016; Chellaiah, 2018; Karimpour et al., 2018; Wright et al., 2019).

High MIC values against two types of heavy metals recorded for Citrobacter freundii, Klebsiella oxytoca, Proteus vulgaris and Salmonella Typhimurium can be explained by the fact that Enterobacteriaceae species are able to resist toxic metals, which are widely spread in the natural environment. High levels of metal ions represent a stress factor for Enterobacteria, which then enlarge their plasmids under stress conditions. However, under appropriate conditions, plasmids shrink and disappear and can adapt to the environment. Furthermore, the resistance of the Enterobacteriaceae members to heavy metal salts is also related to metal pollution in the environment (Çardak and Altug, 2014). Heavy metal resistance of Enterobacteriaceae was showed by many studies (Rafiq et al., 2017; Kyaing et al., 2019; Bhardwaj et al., 2018). Altimera et al. (2012) showed that bacteria were tolerant to copper with MIC value ranging from 3.1 to $4.7 \mathrm{mM}$. In Addition, Mathivanan and Rajaram (2014) studied that some cadmium tolerant bacteria able to tolerance up to $400 \mathrm{mg} / \mathrm{L}$ of $\mathrm{Cd}^{2+}$ which were isolated from the polluted coastal. Irawati et al. (2017) identified indigenous heavy metal tolerant bacteria from Kemisan River and the highest copper tolerant bacteria showed MIC value of $10 \mathrm{mM}$ showing those isolates were used for further study of copper contamination control.

The Aeromonas hydrophila strain (KZ6) was the isolate showing the lowest metalresistant capacity compared to other bacteria, which could be related to the toxic effect 
of metals on this bacterial cells. Moreover, microorganisms can interact with heavy metal via many mechanisms and different level of metal tolerant level might be due to different types of mechanisms such as bioaccumulation and biosorption processes within each isolates (Kyaing et al., 2019).

The reason why microbial populations differ so hugely in their ability to tolerate such deadly pollutants can be explain by the fact that such variable metal tolerance behavior occurring naturally among microbes towards various heavy metals could be due to (i) the differences in available macro and micro nutrient elements in growth media/water supporting bacterial growth (ii), variable genetic constituents of bacterial strains and (iii) the growth conditions/environmental variables affecting the bacterial growth (Rizvi et al., 2019).

\section{Extraction and estimation of metallothionein (MT)}

Considering the importance of MTs in metal detoxification, the five best isolates (KZ2, KZ5, KZ8, KZ10 and KZ11) were screened to see whether these strains were able to induce MTs production while growing in the presence of $\mathrm{Cu}$ and $\mathrm{Cd}$. Indeed, the five strains exhibited greater production of MTs in the presence of both $\mathrm{Cu}$ and $\mathrm{Cd}$, suggesting an obvious role of metals in MTs induction (Fig. 2). Maximum MT levels were recorded for Pseudomonas aeruginosa KZ5, Proteus vulgaris KZ10 and Klebsiella oxytoca KZ8 (77.13, 78.11 and $90.53 \mathrm{nmol} \mathrm{MT} / \mathrm{g}$ bacterial biomass, respectively). The metallothioneins have been found in some limited Procaryota, including cyanobacteria, pseudomonads and mycobacteria (Genetyki et al., 2017). The first bacterial metallothionein SmtA was characterized in Synechococcus PCC 7942 function as sequester and detoxifies $\mathrm{Cd}^{2+}$ and $\mathrm{Zn}^{2+}$. Later SmtA also is found in the Anabaena PCC 7120, P. aeruginosa and Pseudomonas putida (Malekzadeh and Shahpiri, 2017). Subsequently, proteins similar to SmtA were found in other cyanobacteria and $\gamma$-proteobacteria, such as the genus Pseudomonas. All those bacterial proteins similar to SmtA were included in BmtA (bacterial MTs) family (Gutiérrez et al., 2019). Furthermore, Gram-negative bacterial species such as E. coli, Serratia liquefaciens, Klebsiella pneumoniae was recognized on production of intracellular cadmium-binding proteins (Kumar et al., 2019). The bacterial MTs differ in terms of primary structure, the number and type of metal ions they bind, as well as with regard to their physiological functions. The expression of bacterial MTs is regulated by metals via metalosensors (Genetyki et al., 2017). MTs from Enterobacteriaceae seem to be involved in zinc and copper homeostasis, while in Pseudomonas they are linked to cadmium detoxification.

Results revealed that the MT level increased significantly in a metal concentration ( $r=0.936, p=0.006$ ). Generally, the MT expression level is dose-dependent on heavy metals (Walker et al., 2014). In bacteria strains, intracellular sequestration of metals is mostly based on the presence of metallothionein which is involved in many cellular functions, particularly in the transport, storage and detoxification of metals (Chudobova et al., 2015). Therefore, an increased concentration of metallothionein can be important for homeostasis and detoxification of metals to acquire resistance to heavy metal in the bacterial strains isolated from surface water. Accordingly, the ability of bacteria isolates express metallothionein due to the expose of heavy metals compared to control (without metal) was tested. Numerous reports have shown that MTs play crucial roles in maintaining metal homeostasis and protect against heavy metal toxicity through intracellular sequestration (Chudobova et al., 2015). Mikowska et al. (2018) and Xu et 
al. (2018) revealed that MTs are implicated in homeostasis of essential heavy metals such as copper, detoxification of noxious metal cations such as cadmium. Also, Abbas et al. (2017) indicate that the cadmium-resistant bacteria have also adopted the strategy to bind the cadmium with intracellular binding proteins (bacterial metallothioneins).

According to the literature, MT is predominantly a $\mathrm{Cu}$-binding protein, but results of this part revealed that $\mathrm{Cd}$ was however, found, to be a superior inducer of MTs compared to $\mathrm{Cu}(p=0.005)$. The strength of MT defense depends on several factors connected with the metal characteristics and organism attributes (Mikawska et al., 2018). Therefore, an increase in MT levels may reflect an elevated demand to detoxify Cd. Wang et al. (2014) reviewed the recent advances of characteristics, functions and applications of metallothionein and they demonstrated that $\mathrm{Cd}$ was the most potential for MTs induction among three metals (i.e., $\mathrm{Cd}, \mathrm{Cu}$, and $\mathrm{Zn}$ ). $\mathrm{Xu}$ et al. (2018) demonstrate that metallothionein- like protein type 3 (CsMTL3) can improve metal tolerance, especially for $\mathrm{Cd}^{2+}$ ions and suggest that the composition and arrangement of $\mathrm{N}$-terminal Cys residues are associated with binding capacity and preference for different metal ions. Similar to our research, habjanic et al. (2018) showed that a Gramnegative bacteria has a histidine-rich Mt with a disordered tail displays higher binding capacity for cadmium than other metal.

\section{Conclusion}

The results of the present study showed that the waters of Seybouse River are under the influences of heavy metal pollution (especially $\mathrm{Cd}$ ). Eleven metal-resistant bacterial strains were isolated and identified from surface water in Seybouse basin. All of the strains were showed the resistance level $\mathrm{Cu}>\mathrm{Cd}$. The isolates Citrobacter freundii, Pseudomonas aeruginosa, Klebsiella oxytoca, Proteus vulgaris and Salmonella Typhimurium showed the high MIC values against $\mathrm{Cd}$ and $\mathrm{Cu}$. These five isolates presented metallothionein induction as its mechanisms of metal resistance. It has been shown that $\mathrm{Cd}$ was found, to be a superior inducer of MTs compared to $\mathrm{Cu}$.

The results obtained in this study, therefore, clearly establish the fact that MTs so generated by bacterial communities in stressed environments could be useful in efficiently detoxifying metal contaminated environments. Hence, the use of bacteria possessing this property of secreting MTs could be explored as a cost effective approach in bioremediation strategies. Further study of the effects of different supplements and conditions in their growth is needed to identify their efficiency as bioremediation agents, where optimization of $\mathrm{pH}$, temperature, and incubation time can influence metal resistance capacity.

Acknowledgements. The research was supported by the General Manager for Scientific Research and Technological Development (DGRSDT). The authors thank Brahmia S., Souadkia K., Soucha I., Benchikh S., Boumaza K., Chitour R., Souilah N.,for their assistance in the manipulations.

Conflict of interests. The authors declare no conflict of interests. 


\section{REFERENCES}

[1] Abbas, S. Z., Rafatullah, M., Hossain, K., Ismail, N., Tajarudin, H. A., Abdulkhalil, H. P. S. (2017): A review on mechanism and future perspectives of cadmium-resistant bacteria. - International Journal of Environmental Science and Technology 15: 243-262.

[2] Aljerf, L., Almasri, N. (2018): A gateway to metal resistance: Bacterial response to heavy metal toxicity in the biological environment. - Annals of Advances in Chemistry 2:32-44.

[3] Alquethamy, S. F., Khorvash, M., Pederick, V. G., Whittall, J. J., Paton, J. C., Paulsen, I. T., Hassan, K. A., Mcdevitt, C. A., Eijkelkamp, B. A. (2019): The role of the CopA copper efflux system in Acinetobacter baumannii virulence. - International Journal of Molecular Sciences 20: 575.

[4] Altimera, F., Yanez, C., Bravo, G. (2012): Characterization of copper resistant bacteria and bacterial communities from copper-polluted agricultural soils of central Chile. - BMC Microbiology 12: 1-12.

[5] Aminot, A., Kérouel, R. (2004): Major physicochemical characteristics. - In: Aminot, A., Kérouel, R. (eds.) Hydrobiology of marine ecosystems: parametres and analyzes. $8^{\text {th }}$ ed., Ifremer, Brest.

[6] Ana, R. L., Garcia-Vazquez, E. (2006): A simple assay to quantify metallothionein helps to learn about bioindicators and environmental health. - Biochemistry and Molecular Biology Education 34(5): 360-363.

[7] Banerjee, S., Gothalwal, R., Sahu, P. K., Sao, S. (2015): Microbial observation in bioaccumulation of heavy metals from the ash dyke of thermal power plants of Chhattisgarh, India. - Advances in Bioscience and Biotechnology 6: 131-138.

[8] Belabed, B. E., Frossard, V., Dhib, A., Turki, S., Aleya, L. (2013): What factors determine trace metal contamination in Lake Tonga (Algeria)? - Environment Monitoring and Assessment 185: 9905-9915.

[9] Belabed, B. E., Meddour, A., Samraoui, B., Chenchouni, H. (2017): Modeling seasonal and spatial contamination of surface waters and upper sediments with trace metal elements across industrialized urban areas of the Seybouse watershed in North Africa. - Environment Monitoring and Assessment 189: 265.

[10] Benhalima, L., Kadri, S., Barour, C., Bensouilah M., Ouzrout, R. (2018): Water Quality Assessment of a Coastal Canal within a Protected Zone in Algeria using Principal Component Analysis. - Indian Journal of Science and Technology 11(32).

[11] Bhardwaj, R.,Gupta, A., Garg, J.K. (2018): Impact of heavy metals on inhibitory concentration of Escherichia coli- a case study of river Yamuna system, Delhi, India. Environment Monitoring and Assessment 190: 674.

[12] Cai, X., Zheng, X., Zhang, D., Iqbal, W., Liu, C., Yang, B., Zhao, X., Lu, X., Mao, Y. (2019): Microbial characterization of heavy metal resistant bacterial strains isolated from an electroplating wastewater treatment plant. - Ecotoxicology and Environmental Safety 181:472-480.

[13] Cañedo-Argüelles, M., Kefford,B., Schäfer, R. (2019): Salt in freshwaters: causes, effects and prospects - introduction to the theme issue. - Philosophical Transaction Royal Society B 374: 20180002.

[14] Çardak, M., Altug, G. (2014): Species distribution and heavy metal resistance of Enterobacteriaceae members isolated from Istanbul Strait. - Fresenius Environmental Bulletin 23(10a): 2620-2626.

[15] Chaoui, W., Attoui, B., Benhamza, M., Bouchami, T., Alimi, L. (2015): Water quality of the plain of El-Hadjar wilaya of Annaba (Northeast Algeria). - Energy Procedia 74: 1174-1181.

[16] Chellaiah, E. R. (2018): Cadmium (heavy metals) bioremediation by Pseudomonas aeruginosa: a minireview. - Applied Water Science 8: 154.

[17] Chen, B., Stein, A. F., Castell, N., Gonzalez-Castanedo, Y., Sanchez De La Campa, A. M., De La Rosa, J. D. (2016): Modeling and evaluation of urban pollution events of 
atmospheric heavy metals from a large $\mathrm{Cu}$-smelter. - Science of the Total Environment 539: 17-25.

[18] Choudhary, S. (2019): In silico analysis of potential metallothioneins in Pseudomonas. - Research Journal of life Sciences, Bioinformatics, Pharmaceutical and Chemical Sciences 5(1): 101-115.

[19] Chudobova, D., Dostalova, S., Ruttkay-Nedecky, B., Guran, R., Rodrigo, M. A. M., Tmejova, K., Krizkova, S., Zitka, O., Adam, V., Kizek, R. (2015): The effect of metal ions on Staphylococcus aureus revealed bybiochemical and mass spectrometric analyses. - Microbiological Research 170: 147-156.

[20] Diop, C. (2014): Study of the contamination, speciation and bioavailability of heavy metal traces in coastal and estuarine waters and sediments in Senegal: Evaluation of potential toxicity. - Ph.D. Thesis. Doctoral Scool Sciences of matter, radiation and the environment, University of Lille 1, France.

[21] Eljaiek-Urzola, M., Romero-Sierra, N., Segrera-Cabarcas, L., Valdelamar-Martínez, D., Quiñones-Bolaños, É. (2019): Oil and grease as a water quality index parameter for the conservation of marine biota. - Water 11: 856.

[22] Genetyki, Z., Biologii, W., Środowiska, O. (2017): Bacterial metallothionein. - Post Mikrobiology 56(2): 171-179.

[23] Giovanella, P., Cabral, L., Costa, A. P., De Oliveira Camargo, A. F., Gianello, C., Bento, F. M. (2017): Metal resistance mechanisms in Gram-negative bacteria and their potential to remove $\mathrm{Hg}$ in the presence of other metals. - Ecotoxicology and Environmental Safety 140: $162-169$.

[24] Guettaf, M., Maoui, A., Ihdene, Z. (2014): Assessment of water quality: a case study of the Seybouse River (North East of Algeria). - Applied Water Science. DOI 10.1007/s13201-014-0245-z.

[25] Gupta, P., Diwan, B. (2017): Bacterial Exopolysaccharide mediated heavy metal removal: A Review on biosynthesis, mechanism and remediation strategies. - Biotechnology Reports 13: 58-71.

[26] Gutiérrez, J. C., De Francisco, P., Amaro, F., Díaz, S., Martín-González, A. (2019): Structural and Functional Diversity of Microbial Metallothionein Genes. - Microbial Diversity in the Genomic Era 387-407.

[27] Habjanic, J., Zerbe, O., Freisinger, E. (2018): A histidine-rich Pseudomonas metallothionein with a disordered tail displays higher binding capacity for cadmium than zinc. - Metallomics 10: 1415-1429.

[28] Holt, J. G., Krieg, N. R., Sneath, P. H. A., Staley, J. T., Williams, S. T. (1994): Bergey's Manual of Determinative Bacteriology (9th ed.). - Williams and Wilkins Press, Baltimore.

[29] Hoque, E., Fritscher, J. (2019): Multimetal bioremediation and biomining by a combination of new aquatic strains of Mucor hiemalis. - Scientific Reports 9: 10318.

[30] Huanga, J., Penga, S., Maoc, X., Lia, F., Guoa, S., Shia, L., Shia, Y., Yua, H., Zeng, G. (2019): Source apportionment and spatial and quantitative ecological risk assessment of heavy metals in soils from a typical Chinese agricultural county. - Process Safety and Environmental Protection 126: 339-347.

[31] Irawati, W., Riak, S., Sopiah, N., Sulistia, S. (2017): Heavy metal tolerance in indigenous bacteria isolated from the industrial sewage in Kemisan River, Tangerang, Banten, Indonesia. - Biodiversitas 18: 1481-1486.

[32] Jaishankar, M., Tseten, T., Anbalagan, N., Mathew, B. B., Beeregowda, K. N. (2014): Toxicity: mechanism and health effects of some heavy metals. - Interdisciplinary Toxicology 7: 60-72.

[33] Jiang, Y., Chao, S., Liu, J., Yang, Y., Chen, Y., Zhang, A., Cao, H. (2017): Source apportionment and health risk assessment of heavy metals in soil for a township in Jiangsu Province, China. - Chemosphere 168: 1658-1668. 
[34] Karimpour, M., Ashrafi, S. D., Taghavi, K., Mojtahedi, A., Roohbakhsh, E., Naghipour, D. (2018): Adsorption of cadmium and lead onto live and dead cell mass of Pseudomonas aeruginosa: a dataset. - Data Brief 18: 1185-1192.

[35] Keevil, W. (2001): Antibacterial properties of cooper and brass demonstrate potential to combat toxic E. coli $\mathrm{O} 157$ outbreaks in the food processing industry (Centre for Applied Microbiology and Research, UK). - In: Symposium on Copper and Health, held in CEPAL, Santiago, Chile. Available online: https://www.copper.org (accessed on 5 January 2019).

[36] Khaled-Khodja, S., Samar, M. H., Durand, G. (2016): Metallic contamination of water and sediment of Boumahra wadi. - Synthèse: Revue des Sciences et de la Technologie 32:135-146.

[37] Kumar, P., Gupta, S., Anurag, B., Soni, R. (2019): Bioremediation of cadmium by mixed indigenous isolates Serratia liquefaciens BSWC3 and Klebsiella pneumoniae RpSWC3 isolated from industrial and mining affected water samples. - Pollution 5(2): 351-360.

[38] Kyaing, M. S., Khaing, M. T., Saing, K. M. (2019): Screening of heavy metal (Lead) and antibiotics resistant soil bacteria from Myanmar industrial sites. - International Journal of Current Microbiology and Applied Sciences 8(4): 1319-1325.

[39] Li, Y., Yang, H., Liu, N., Luo, J., Wang, Q., Wang, L. (2015): Cadmium accumulation and metallothionein biosynthesis in cadmium-treated freshwater mussel Anodonta woodiana. - Plos One 10(2): e0117037.

[40] Li, C., Li, Y., Ding, C. (2019): The role of copper homeostasis at the host-pathogen axis: From bacteria to fungi. - International Journal of Molecular Sciences 20: 175.

[41] Louhi, A., Hammadi, A., Achouri, M. (2012): Determination of some heavy metal pollutants in sediments of the Seybouse River in Annaba, Algeria. - Air, Soil and Water Research 5: 91-101.

[42] Malekzadeh, R., Shahpiri, A. (2017): Independent metal-thiolate cluster formation in Cterminal Cys-rich region of a rice type 1 metallothionein isoform. - International Journal of Biological Macromolecules 96: 436-441.

[43] Manasi, N. R., Rajesh, V. (2016): Evaluation of the genetic basis of heavy metal resistance in an isolate from electronic industry effluent. - Journal of Genetic Engineering and Biotechnology 14: 177-180.

[44] Marzan, L. W., Hossain, M., Mina, S. A., Akter, Y., Azad Chowdhury, A. M. M. (2017): Isolation and biochemical characterization of heavy-metal resistant bacteria from tannery effluent in Chittagong city, Bangladesh: Bioremediation viewpoint. - Egyptian Journal of Aquatic Research 43: 65-74.

[45] Mathivanan, K., Rajaram, R.(2014): Isolation and characterization of cadmium resistant bacteria from an industrially polluted coastal ecosystem on the southeast coast of India. Chemistry and Ecology 30(7): 622-635.

[46] Mikawska, M., Dziublińska, B., Świergosz-Kowalewska, R. (2018): Variation of metallothionein I and II gene expression in the bank vole (Clethrionomys glareolus) under environmental zinc and cadmium exposure. - Archives of Environmental Contamination and Toxicology 75: 66-74.

[47] Mohseni, M., Khosravi, F., Mohajerani, M., Chaichi, M. J. (2014): Bioremediation activity of $\mathrm{Pb}$ (II) resistance Citrobacter sp. MKH2 isolated from heavy metal contaminated sites in Iran. - Journal of Sciences, Islamic Republic of Iran 25(2): 105110 .

[48] Murthy, S., Bali, G., Sarangi, S. K. (2011): Effect of lead on metallothionein concentration in lead resistant bacteria Bacillus cereus isolated from industrial effluent. - African Journal of Biotechnology 10(71): 15966-15972.

[49] Mutiat, F. B. Y., Gbolahan, B., Olu, O. (2018): A comparative study of the wild and mutated heavy metal resistant Klebsiella variicola generated for cadmium bioremediation. - Bioremediation Journal 22(1-2): 28-42. 
[50] Niveshika, S. S., Verma, E., Mishra, A. K. (2016): Isolation, characterization and molecular phylogeny of multiple metal tolerant and antibiotics resistant bacterial isolates from river Ganga,Varanasi, India. - Cogent Environmental Science 2: 1273750.

[51] Official Journal of Algerian Republic (OJAR). (2014): Executive decree $n^{\circ} 14-96$ March 04th 2014. - Setting the quality goals of superficial and ground waters intended for the water supply of the populations.

[52] Qin, W., Zhao, J., Yu, X., Liu, X., Chu, X.,Tian, J., Wu, N. (2019): Improving cadmium resistance in Escherichia coli through continuous genome evolution. - Frontiers in Microbiology 10: 278.

[53] Rafiq, M., Hayat, M., Anesio, A. M., Jamil, S. U. U., Hassan, N., Shah, A. A. (2017): Recovery of metallo-tolerant and antibiotic resistant psychrophilic bacteria from Siachen glacier, Pakistan. - PLoS ONE 12(7): e0178180.

[54] Rizvi, A., Ahmed, B., Zaidi, A., Khan, M. S. (2019): Heavy metal mediated phytotoxic impact on winter wheat: oxidative stress and microbial management of toxicity by Bacillus subtilis BM2. - Royale Society of Chemistry Advances 9: 6125-6142.

[55] Talbi, H., Kachi, S. (2019): Evaluation of heavy metal contamination in sediments of the Seybouse River, Guelma - Annaba, Algeria. - Journal of Water Land Development 40(I-III): 81-86.

[56] Türetken, P. S. Ç., Altuğ, G., Çardak,M., Güneş, K. (2019): Bacteriological quality, heavy metal and antibiotic resistance in Sapanca Lake, Turkey. - Environment Monitoring and Assessment 191: 469.

[57] Vidhyaparkavi, A., Osborne, J., Babu, S. (2017): Analysis of zntA gene inenvironmental Escherichia coli and additional implications on its role in zinc translocation. -3 Biotech 7: 9.

[58] Walker, C. J., Gelsleichter, J., Adams, D.H., Manire, C.A.(2014): Evaluation of the use of metallothionein as a biomarker for detecting physiological responses to mercury exposure in the bonnethead, Sphyrna tiburo. - Fish Physiology and Biochemistry 40(5): 1361.

[59] Wang, W. C., Mao, H., Ma, D. D., Yang, W. X. (2014): Characteristics, functions, and applications of metallothioneinin aquatic vertebrates. - Frontiers in Marine Science 1(34).

[60] Wright, B. W., Kamath, K. S., Krisp, C., Molloy, M. P. (2019): Proteome profiling of Pseudomonas aeruginosa PAO1 identifies novel responders to copper stress. - BMC Microbiology 19: 69.

[61] Xiaoyan, L., Mou, R., Cao, Z., Xu, P., Wu, X., Zhu, Z., Chen, M. (2016): Characterization of cadmium-resistant bacteria and their potential for reducing accumulation of cadmium in rice grains. - Science of the Total Environment 569: 97-104.

[62] Xu, X., Duan, L., Yu, J., Su, C., Li, J., Chen, D., Zhang, X., Song, H., Pan, Y. (2018): Characterization analysis and heavy metal-binding properties of CsMTL3 in Escherichia coli. - FEBS Open Bio 8: 1820-1829.

[63] Zaigham, H., Anwar, Z., Khattak, K. U., Islam, M., Ullah Khan, R., Khattak, J. Z. K. (2012): Civic pollution and its effect on water quality of River Toi at District Kohat, NWFP. - Research Journal of Environmental and Earth Sciences 334-339. 